\title{
A Bayesian-based framework for advanced nature-based tourism model
}

\author{
Roxana Norouzi Isfahani \\ University of Florence, Florence, Italy \\ Ahmad Talaee Malmiri \\ University of Tehran, Tehran, Iran \\ Ahmad BahooToroody \\ University of Florence, Florence, Italy, and \\ Mohammad Mahdi Abaei \\ Delft University of Technology, Delft, The Netherlands
}

A Bayesianbased framework

\begin{abstract}
Purpose - Nature-based tourism (NBT) blossoming requires sound monitoring models to maximize its potential in the tourism industry. Cooperation of different segments from nature to economy will lead to a sustainable NBT. Therefore, the qualitative and quantitative relation between these subdivisions has to be investigated.

Design/methodology/approach - This paper proposes an advanced NBT model for the design of an optimum tourism system. To this end, Bayesian network $(\mathrm{BN})$ has been implemented to characterize the impact of each subsector on NBT.

Findings - The outcomes of this study can help the tourism managers, policymakers and related organizations to find the optimum approach to achieve a continuous improvement in the system. To demonstrate the applicability of the methodology, two cases of observations are considered.
\end{abstract}

Originality/value - The originality of the work is well demonstrated in the literature review of the paper.

Keywords Nature-based tourism, Bayesian network, Dynamic modeling

Paper type Research paper

\section{Introduction}

The potentials of tourism economy, as roughly $10 \%$ of gross domestic product (GDP) (Council, 2007), have made governments and private sectors enthused to allocate resources for fulfilling its capacities continuously. To this end, tourism has been divided into different subcategories such as cultural tourism, urban tourism, rural tourism and so on, so that all the positive aspects and the strengths of each category would be enforced (Ashworth and Page, 2011; MacDonald and Jolliffe, 2003; Park and Yoon, 2009; Pearce, 2001; Richards, 2007; Smith, 2009; Wilson et al., 2001).

Globally, we are facing new consumer motives and competitive growth of demands in tourism sector, which can be met by alternative forms of tourism (Cuculeski et al., 2015). In this regard, nature-based tourism (NBT) as the most accelerated growing sector in tourism (Bell et al., 2009), has recently attracted large attention (Akama, 1996; Balmford et al., 2009; Ceballos-

(C) Roxana Norouzi Isfahani, Ahmad Talaee Malmiri, Ahmad BahooToroody and Mohammad Mahdi Abaei. Published in Journal of Asian Business and Economic Studies. Published by Emerald Publishing Limited. This article is published under the Creative Commons Attribution (CC BY 4.0) licence. Anyone may reproduce, distribute, translate and create derivative works of this article (for both commercial and non-commercial purposes), subject to full attribution to the original publication and authors. The full terms of this licence may be seen at http://creativecommons.org/licences/by/4.0/legalcode.

Received 1 November 2020 Revised 6 April 2021 17 June 2021

Accepted 4 July 2021 
Lascurain, 1996; Coghlan and Buckley, 2012; Fredman and Tyrväinen, 2010; Kuenzi and McNeely, 2008). Finding a unified definition of NBT has boasted to be difficult as there is no clear-cut definition for outdoor recreationists, and specifying services related to a specific activity is hard. However, some aspects and descriptions of NBT can be illustrated by looking into broader contexts within literature. While these descriptions include concepts such as "environmental awareness or nature conservation motives as an inherent target," in practice, some activities such as motorized activities that can harm the nature and environment are given to clients (Fredman and Tyrväinen, 2010). As discussed by Fredman and Tyrvä inen (2010), NBT is related to leisure activities happening in nature areas and its main components are the visitor and experiences of or in nature.

As suggested by UNWTO, nearly $10-20 \%$ of international visits are related to nature experience. However, assessing the economic gains of NBT can be challenging, as these benefits should be assessed across different economic fields such as lodging, transportation and some parts of food service industry. Also, it is worth mentioning that the activities directly related to NBT do not generate large revenues in tourism sector compared to traditional services in this sector such as transportation, food and accommodation (Fredman and Tyrväinen, 2010). While some reports (Balmford et al., 2009; Goodwin, 1996; Mastny and Peterson, 2001) indicate that NBT is one of the fastest growing sectors of the world's largest industry, a recent and widely published paper (Pergams and Zaradic, 2008) states that the number of tourists visiting natural areas in USA and Japan has declined since late 1980s. Balmford et al. (2009) clarified this apparent paradox by looking at temporal trends in visitors' number in 280 protected areas from 20 countries. Their study proved that despite important recessions in some countries, NBT is still far from declining.

Fossgard and Fredman (2019) in an article named "Dimensions in the nature-based tourism experiencescape: An explorative analysis" argue that "Items and features of natural environments are inherit to nature-based tourism." Focusing on experience in tourism has expanded resource requirements, and this is also true in NBT. Although these resources may vary between different activities related to NBT, some of the more important resources for having better experience can be scenic landscape, nice weather, campsite with bonfires and space and time for social interaction (Fossgard and Fredman, 2019).

Visiting natural areas besides having some benefits such as increasing environmental awareness, boosting physical and mental health and also refreshment can lead to some environmental and social issues. These issues should be addressed by adopting constructive managing approaches toward preserving these areas. NBT managers, to abate the environmental impacts, need to have knowledge about the spatial and temporal distribution of different kinds of activities done in NBT, meanwhile trying to improve visitors' experience.

Although various uncertainty models have been addressing different issues such as tourist loyalty, tourist arrivals, tourist behavior and so on throughout tourism sector, explanation of NBT behavior using a promising probabilistic has been neglected in tourism literature (Assef et al., 2017; Baggio et al., 2010; Hsu et al., 2008, Casagrandi and Rinaldi, 2002; Smeral, 1988; Tyrrell and Johnston, 2008). As a result, to create a dynamic predictive model to quantify the explanation of behavior of elements incorporating in a sustainable NBT, a probabilistic modeling tool is implemented to be able to reason under the uncertainty. Among the different probabilistic-prediction models, two models of maximum likelihood estimation (MLE) and Bayesian statistics were found to be recommended by the researchers (Assaf and Tsionas, 2015; Hsu et al., 2008; Hsu et al., 2012). There exist three main reasons for Bayesian method to be superior to other methods. Firstly, it is a promising tool that allows the comprehensive reflection of available knowledge about the process. Secondly, in comparison to other tools such as analytic hierarchy process (AHP) and factor analysis (FA), BN performs better in quantifying the 
uncertainty and solving decision-making problems when extended to an influence diagram. Thirdly, in a Bayesian approach, it is also possible to convert continuous random variables into a discrete space, enabling the inference of more complicated stochastic relationships among many parameters. That means each variable involved in the problem can be analyzed explicitly rather than in a binary space.

$\mathrm{BN}$ as a probabilistic modeling tool has been widely implemented for parametric and nonparametric assessment in tourism systems. (Assaf and Tsionas, 2015; Hsu et al., 2012; Huang and Bian, 2009; Ticehurst et al., 2007; Wang et al., 2008). As a parametric model, C.-I). Hsu et al. (2008) merged BN with linear structural relation model (LISREL), to consider the factors affecting tourism loyalty and predict the level of the tourists' loyalty. In total, 452 valid samples from tourists with the tour experience of the Toyugi, Taiwan, were accounted to conduct the proposed methodology. Also, as a nonparametric $\mathrm{BN}$, in very recently published article (Assaf et al., 2019) established Bayesian ridge regression to a tourism data set in order to treat the biased constant as a parameter of inference. The model proposed to find the optimum solution for a multicollinearity problem as the most important misconception in tourism research field. In the present paper, a well-known statistical approach is applied on NBT to characterize the impact of influencing factors, one by one, on condition of NBT. To this end, a BN is established to specify the variation of each factor according to different indexes of NBT. Regarding the NBT optimization, the most critical influencing factor is then identified. That is, which factor has more impact on the sustainability of NBT and controlling the condition of which factor leads to optimal continuous development in NBT. In this regard, a general model is proposed to help different stakeholders in tourism sector, governments and policymakers to evaluate the proposed NBT influencing parameters. A case study of Gilan province in north of Iran has been accounted to demonstrate the applicability of proposed methodology.

The remainder of the paper is structured as follows: section 2 is devoted to the model specification. It is followed by the application of methodology in section 3 , while the conclusion is treated in section 4 .

\section{Methodology}

\subsection{Bayesian network}

Based on the probability theory, BN is a directed acyclic graph (DAG) including a set of arrows and nodes. The nodes are variables through which the arrows represent the conditional dependencies. BN estimates the joint probability distribution of a set of random variables as follows:

$$
P\left(X_{1}, X_{2}, \ldots, X_{n}\right)=\prod_{i=1}^{n} P\left(X_{i} \mid P a\left(X_{i}\right)\right)
$$

Where $\mathrm{Pa}\left(X_{i}\right)$ is the parent set of variables, $X_{i}$. Take as an example, the joint probability distribution of the random variables $X_{1}, X_{2}, X_{3}$ and $X_{4}$, demonstrated in Figure 1, is $P\left(X_{1}, X_{2}, X_{3}, X_{4}\right)=P\left(X_{1}\right) P\left(X_{2} \mid X_{1}\right) P\left(X_{3} \mid X_{1}, X_{2}\right) P\left(X_{4} \mid X_{2}\right)$.

$\mathrm{BN}$ is also able to be updated in the light of new evidence given by:

$$
P(X \mid E)=\frac{P(E \mid X) P(X)}{\sum_{X} P(X, E)}
$$

Extensive range of applications in the fields of marketing, management, engineering and so on carried out by means of BNs are reviewed and provided by Barber (2012), Neapolitan (2004), Scutari (2014). A Bayesian-
based
framework 


\section{JABES}

Figure 1.

A conventional Bayesian network

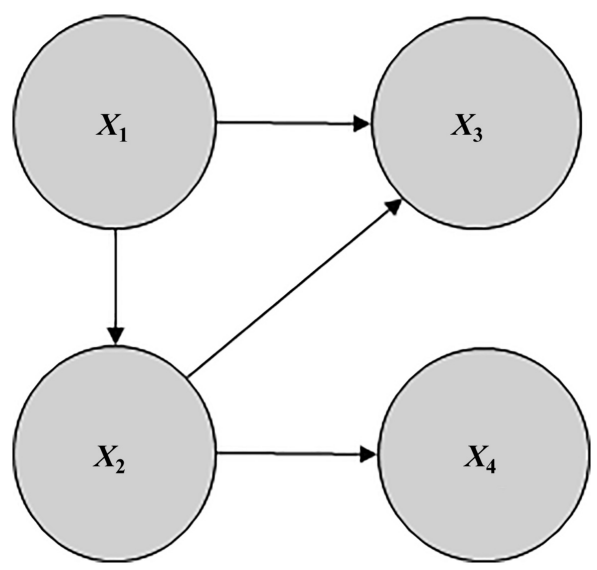

\subsection{Model specification}

A general model is proposed and mapped on $\mathrm{BN}$ accordingly. The presented model at first aimed at including the key factors and subdivisions of NBT and then, building the relationship between each factor through the conducted BN. According to the literature and evidences from tourist-related organizations, there is a limitation regarding the data set of NBT sector in different forms and destinations. To cope with this limitation, $\mathrm{BN}$ is selected as the main approach for the model since it is able to execute reasoning under uncertainty. In the proposed model, 16 factors are assigned to describe the variability of NBT considering different conditions of each of these factors. These 16 factors are categorized into three levels; first level includes the factors with primary influence on the NBT. The second and third levels are connected with NBT indirectly through their connections with the factors of first level. Table 1 illustrates influence factors for uncertainty modeling of NBT in three levels of interaction.

As it can be seen in Figure 2, there are three factors classified as the first level; beautiful scenery (BS), good climate (GC) and socioeconomic factors (SEF).

BS as a significant and main potential of NBT is verified through three states: whether these places are well-equipped, equipped or nonequipped. GC is set as another influencing node for NBT with two states: compliance and noncompliance. As the last first-level node, $\mathrm{SEF}$ is evaluated given the efficiency of their preprogrammed plan.

The variability of BS is addressed by three second-level factors. Figure 3 illustrates the relationship of BS with its parents. Accordingly, the tour guide parameter is accounted to depict the coverage of tour guides in the considered destination, based on four cases: fully available, available, partially available and rarely available. In order to reduce the uncertainty associated with the estimation of coverage of tour guides, two popular kinds of tour guide, application-based and human-based guide, are assigned as the descendent of this node (see Figure 3). Tour guide parameter was considered as a subcategory of BS, as the explanations given by guides can enhance the perception of visitors, visiting a particular nature reserve. The other influencing factor of NBT, categorized as the second-level factor, is protected area. This node aims at evaluating the security protection of the considered destination for tourists. Three states of fully protected, partially protected and nonprotected are taken into account to show the prior knowledge of this node. The other second-level influencing parameter on the treatment of BS management is the level of popularity of the considered nature. To this end, the level of popularity is divided into three states; advertised, partially advertised and unknown.

GC variable is characterized as an observation for two second-level key factors of NBT (see Figure 4). The weather parameter is specified by five states; cloudy and foggy, sunny, rainy, 
snowy, windy. In order to reduce the uncertainty, probability density function (PDF) of weather condition should be obtained based on the weather data history. Based on the trend and the extreme values, MLE or least-squares estimation (LSE) can be used to determine the most appropriate probability distribution for the data set. Due to efficiency in the calculations, consistency and parameterization invariance, MLE has been recommended in previous research studies (BahooToroody et al., 2019; Leoni et al., 2018; Myung, 2003). Subsequently,
A Bayesianbased framework

\begin{tabular}{|c|c|c|c|c|c|}
\hline & Main factors & & $\begin{array}{l}\text { Second-level } \\
\text { factors }\end{array}$ & Third-level factors & \\
\hline \multirow{8}{*}{$\begin{array}{l}\text { NBT uncertainty } \\
\text { modelling }\end{array}$} & \multirow[t]{3}{*}{ Beautiful scenery } & \multirow[t]{3}{*}{ (BS) } & Protected area & - & \\
\hline & & & Well known & _- & \\
\hline & & & Tour guide & Application-based & \\
\hline & Good climate & (GC) & Weather & $\begin{array}{l}\text { Human-based } \\
-\end{array}$ & \multirow{5}{*}{$\begin{array}{l}\text { Table 1. } \\
\text { The representation of } \\
\text { influence factors for } \\
\text { uncertainty modelling } \\
\text { of NBT considering } \\
\text { different level of } \\
\text { interactions }\end{array}$} \\
\hline & \multirow[t]{4}{*}{$\begin{array}{l}\text { Socioeconomic } \\
\text { factors }\end{array}$} & \multirow[t]{4}{*}{ (SEF) } & $\begin{array}{l}\text { Accommodation } \\
\text { Facilities }\end{array}$ & - & \\
\hline & & & Accessibility & Transportation system & \\
\hline & & & & $\begin{array}{l}\text { Transportation } \\
\text { infrastructures }\end{array}$ & \\
\hline & & & Amenities & - & \\
\hline
\end{tabular}

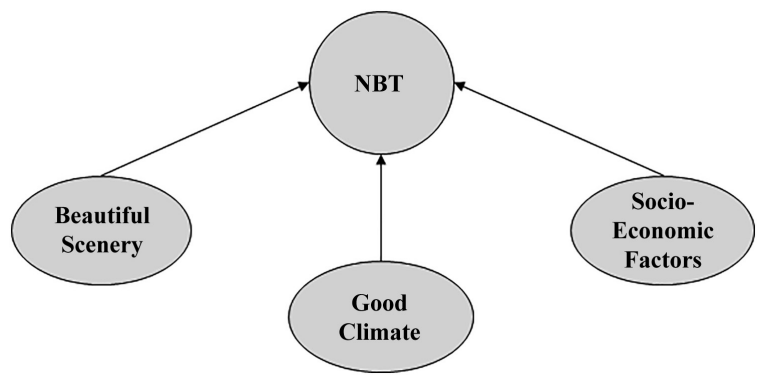

Figure 2 . Proposed generic BN for nature-based tourism

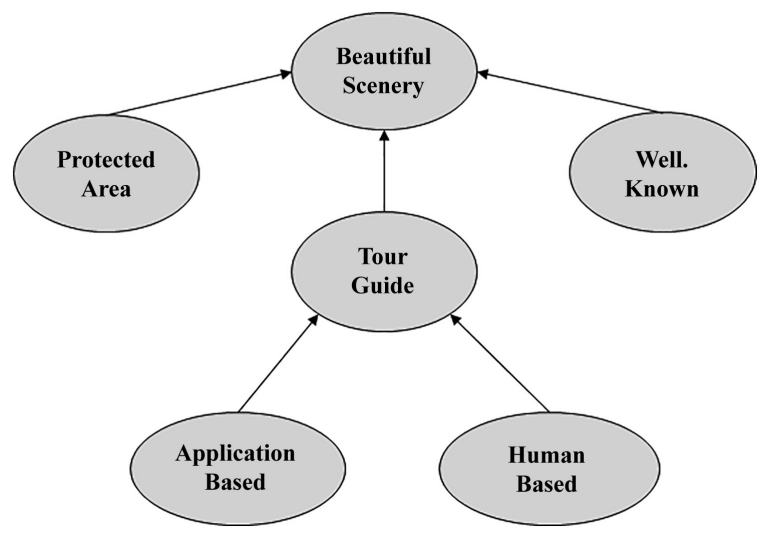

Figure 3. The proposed BN for beautiful scenery 


\section{JABES}

Figure 4.

Developed good climate BN model
Figure 5.

Suggested BN for socioeconomic factors
MLE is recommended to be adopted in the present model and PDF of weather to be accordingly discretized. Besides, the nature parameter as another parent node of GC is described generally through the beaches, mountains, deserts, jungles and plains. These five segments of nature are specified generally in order to be able to cover all the NBTs in different locations. As a result, each of these five states can be eliminated or selected given the geographical and continental features of the considered destination.

Four second-level and two third-level factors are established to predict the posterior probability of SEF based on the degree of planning, well or poor planning, as shown in Figure 5. Accessibility, facilities, amenities and accommodation are the contributors of second level. Furthermore, the accessibility is given as the evidence of transportation systems and transportation infrastructure. It is worth mentioning that the most conspicuous difference between amenities and facilities is that amenities refer to the software and hardware that are allocated for enjoyment, while facilities are the things designing to fulfill the needs.

\section{Application of methodology}

\subsection{Case study}

One of the most astonishing spots of Iran is Gilan province, which lies along the Caspian Sea. This province is considered as the case study to illustrate the advance of proposed methodology. Gilan with $5 \mathrm{~m}$ tourists (inbound and domestic) per year is accounted as one of the most touristic places in Iran. The province has a population of about 2,530,696 people in the area of $14,042 \mathrm{~km}^{2}$ (5,422 sq. mi) resulting in a density of $180 / \mathrm{km}^{2}$ (470/sq. mi). Rasht is the most populated and important city of the province and known as its capital city. Both welladvertised and partially known natures of this province are gathered and reported in Table 2.
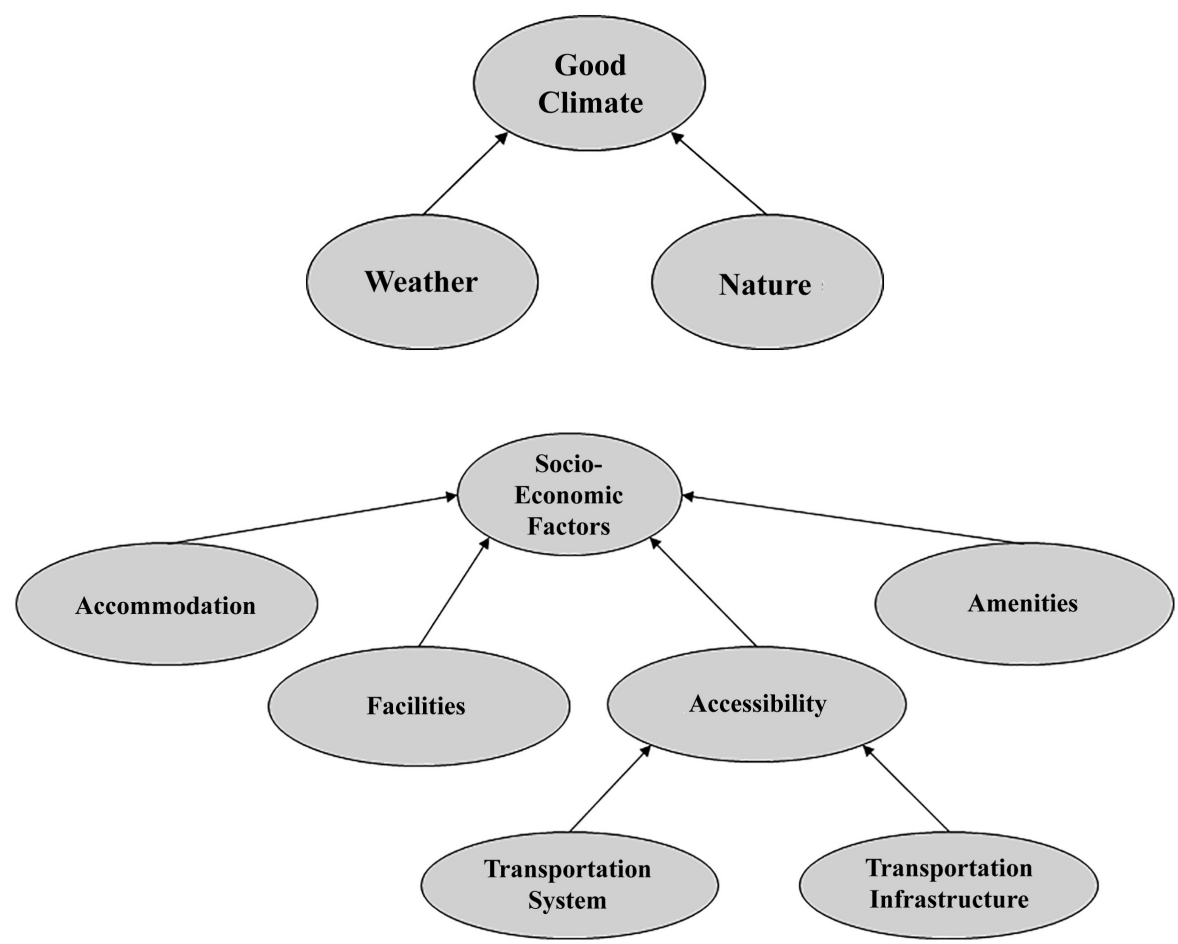


\begin{tabular}{|c|c|c|c|c|}
\hline Beautiful scenery & $\begin{array}{l}\text { Distance to rasht* } \\
\text { (kilometers) }\end{array}$ & Well-known & $\begin{array}{c}\text { Application tour guide } \\
\text { number }\end{array}$ & $\begin{array}{l}\text { A Bayesian- } \\
\text { based }\end{array}$ \\
\hline Asalem to khalkhal road & 126 & $\begin{array}{l}\text { Well- } \\
\text { advertised }\end{array}$ & 5 & \\
\hline Laton waterfall & 174 & $\begin{array}{l}\text { Partially } \\
\text { known }\end{array}$ & 0 & \\
\hline Vistan lake & 90.2 & $\begin{array}{l}\text { Partially } \\
\text { known }\end{array}$ & 0 & \\
\hline Sheytan kuh waterfall & 47.8 & $\begin{array}{l}\text { Well- } \\
\text { advertised }\end{array}$ & 4 & \\
\hline Masal countryside & 60.9 & $\begin{array}{l}\text { Well- } \\
\text { advertised }\end{array}$ & 5 & \\
\hline Al-nazha plain & 89.6 & $\begin{array}{l}\text { Partially } \\
\text { known }\end{array}$ & 0 & \\
\hline Estil lagoon & 173 & $\begin{array}{l}\text { Partially } \\
\text { known }\end{array}$ & 0 & \\
\hline Soostan lagoon & 48.1 & $\begin{array}{l}\text { Partially } \\
\text { known }\end{array}$ & 0 & \\
\hline Gissoom jungle & 84.5 & $\begin{array}{l}\text { Well- } \\
\text { advertised }\end{array}$ & 3 & \\
\hline Kayakaleh wetland & 74.8 & $\begin{array}{l}\text { Partially } \\
\text { known }\end{array}$ & 0 & \\
\hline Masouleh village & 62.2 & $\begin{array}{l}\text { Well- } \\
\text { advertised }\end{array}$ & 5 & \\
\hline Safra basteh village & 42.4 & $\begin{array}{l}\text { Partially } \\
\text { known }\end{array}$ & 0 & \\
\hline Eynak lagoon & 5.8 & $\begin{array}{l}\text { Well- } \\
\text { advertised }\end{array}$ & 1 & \\
\hline Ashkoor & 105 & $\begin{array}{l}\text { Partially } \\
\text { known }\end{array}$ & 0 & \\
\hline Avishoo cave & 81.8 & $\begin{array}{l}\text { Partially } \\
\text { known }\end{array}$ & 0 & \\
\hline Olasbelangah countryside & 80.6 & $\begin{array}{l}\text { Partially } \\
\text { known }\end{array}$ & 3 & \\
\hline Visadar waterfall & 99.5 & $\begin{array}{l}\text { Well- } \\
\text { advertised }\end{array}$ & 4 & \\
\hline Mount Dorfak & 95 & $\begin{array}{l}\text { Partially } \\
\text { known }\end{array}$ & 0 & \\
\hline The village of Siahkeshan & 110 & $\begin{array}{l}\text { Partially } \\
\text { known }\end{array}$ & 0 & \\
\hline Subatan & 138 & $\begin{array}{l}\text { Well- } \\
\text { advertised }\end{array}$ & 0 & \\
\hline Saravan Forest Park & 17.5 & $\begin{array}{l}\text { Well- } \\
\text { advertised }\end{array}$ & 0 & \\
\hline Sarvelat & 108 & $\begin{array}{l}\text { Partially } \\
\text { known }\end{array}$ & 0 & \\
\hline Menjil & 84.5 & $\begin{array}{l}\text { Well- } \\
\text { advertised }\end{array}$ & 3 & \\
\hline Lounak waterfall & 59.5 & $\begin{array}{l}\text { Partially } \\
\text { known }\end{array}$ & 0 & \\
\hline \multirow[t]{2}{*}{ Varzan waterfall, Subatan } & 138 & $\begin{array}{l}\text { Partially } \\
\text { known }\end{array}$ & (continus & $\begin{array}{r}\text { Table } 2 . \\
\text { List of Gilan's beautiful } \\
\text { scenery }\end{array}$ \\
\hline & & & (continued) & scenery \\
\hline
\end{tabular}




\begin{tabular}{lclc}
\hline Beautiful scenery & $\begin{array}{c}\text { Distance to rasht* } \\
\text { (kilometers) }\end{array}$ & Well-known & $\begin{array}{c}\text { Application tour guide } \\
\text { number }\end{array}$ \\
\hline $\begin{array}{l}\text { The village of Salansar, } \\
\text { rudbar }\end{array}$ Saqalaksar Dam & 66 & $\begin{array}{l}\text { Partially } \\
\text { known }\end{array}$ & 0 \\
Rudkhan castle & 18.1 & $\begin{array}{l}\text { Well- } \\
\text { advertised }\end{array}$ & 1 \\
Kiashahr jungle park & 49.2 & $\begin{array}{l}\text { Well- } \\
\text { advertised }\end{array}$ & 5 \\
Haji bekandeh coastal area & 48.7 & $\begin{array}{l}\text { Well- } \\
\text { advertised }\end{array}$ & 0 \\
Mohtasham Garden & 37 & $\begin{array}{l}\text { Partially } \\
\text { known }\end{array}$ & 0 \\
Anzali lagoon & 1.1 & $\begin{array}{l}\text { Partially } \\
\text { known } \\
\text { Well- } \\
\text { advertised } \\
\text { Partially } \\
\text { known } \\
\text { Sartially } \\
\text { known } \\
\text { Partially } \\
\text { known }\end{array}$ & 0 \\
Siahkal-Deylaman road & 50.2 & 68 & 4 \\
Gissoom beach & 57.4 & 97.3 & 0
\end{tabular}

Table 2.

\subsection{Validation of proposed model}

To set up the developed probability network, relevant factors for the 16 NBT are considered, which are presented in Table 1 . According to the discussion made in section 2.2, the proposed $\mathrm{BN}$ is adopted to the case study and illustrated in Figure 6. The Bayesian analyses were carried out in GeNIe 2.2 program, which is a tool for artificial intelligence modeling and machine learning with BNs and other types of graphical probabilistic models.

The root nodes of $\mathrm{BN}$ are quantified based on the data provided by local governmental organizations (CHHTOI, 2018; IRIMO, 2018; IRSO, 2018; MEAF, 2018; MRUD, 2018), documents and expert judgment. Accordingly, expert judgment is applied to estimate the state of seven nodes (well-known, protected area, facilities, transportation system, transportation infrastructure, amenities and accommodation). Besides, documents of local organizations and literature (Coughlin, 2006; Stilo, 1981) are used to calculate the rest of nodes (application-based, human-based, weather and nature). The data gathered from the experts for well-known and protected area nodes are listed in Table 3 and Table 4, respectively. It should be mentioned that in addition to well-known and partially known spots, the unknown beautiful sceneries of Gilan nature were also addressed by experts through the proposed BN to reduce the associated uncertainty. The prior probability of the other five nodes (facilities, transportation system, transportation infrastructure, amenities and accommodation), which were supposed to be explained by experts, are set into BN, depicted in Figure 6 .

Five tourism-based applications have been designed, which cover Gilan province (CHHTOI, 2018). Twelve BSs are covered by at least one of the applications while the rest of them have no application-based guide (see Table 1). Besides, the probability of human-based guide node is defined in three states: lower than 250 (H1), between 250 and 500 (H2) and more than 500 (H3) human tour guides. The number of BSs having human guide of each interval is reported in Table 5 and fed into $\mathrm{BN}$ accordingl. The relevant historical date for the environment considered in the case study presented in the Figure 7 . The observations and 


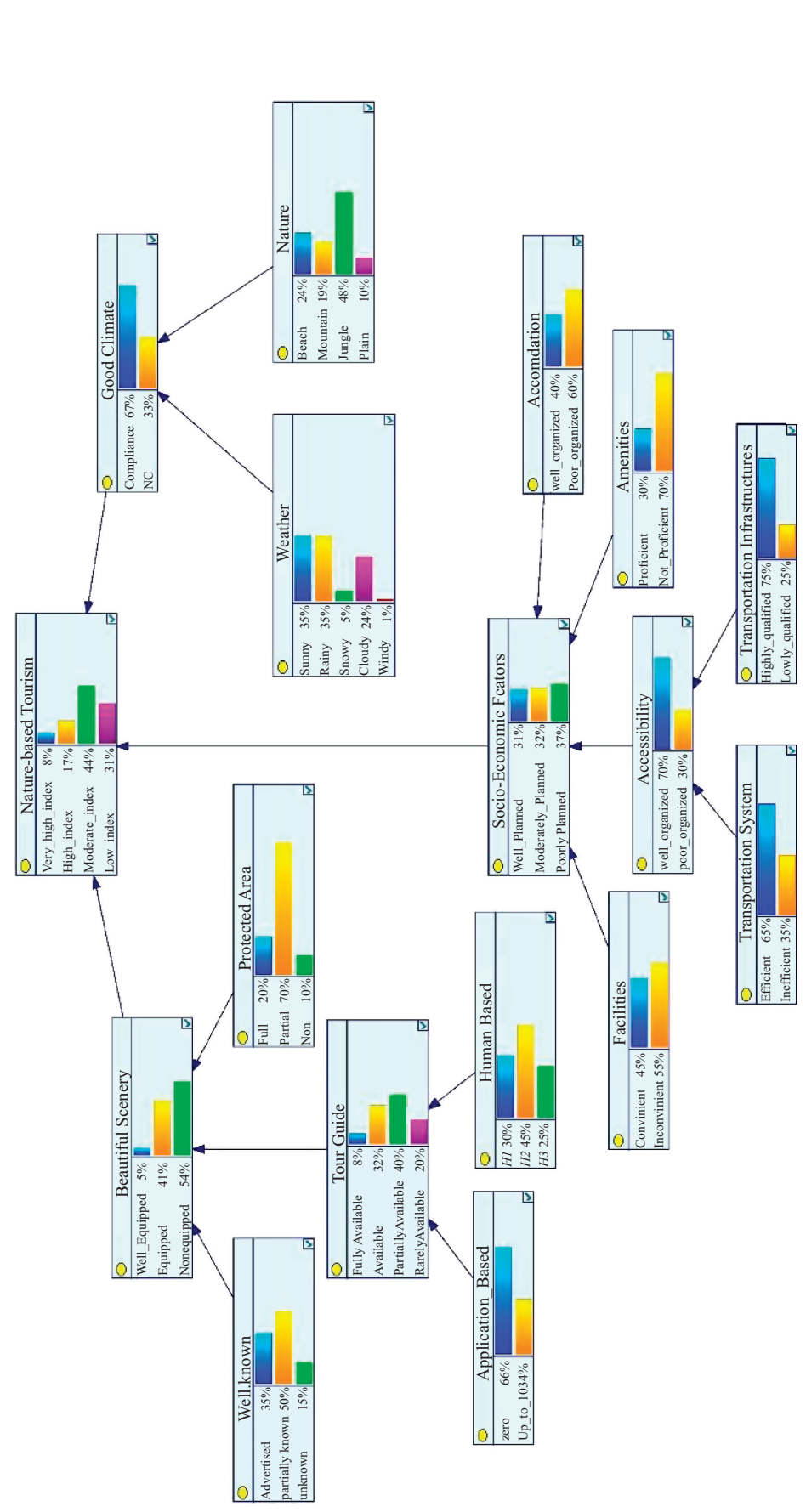
A Bayesian-
based
framework

Figure 6. Adopted proposed BN based on Gilan's nature-based tourism 


\section{JABES}

relevant probability of occurrences of yearly weather, sunny hours, windy days, rainfalls, foggy weather and snow reports are described respectively.

Given aforementioned discussion in section 2.2, the MLE is adopted in the present study for five weather conditions based on historical data provided by (IRIMO, 2018; WWO, January 2014), and the mean of each PDF is taken into account as the portion of that weather condition in a year (listed in Table 6). The coverage of each nature engaging environment was also filled using local governmental documents (CHHTOI, 2018; MRUD, 2018) and reported in Table 7.

\section{Result and discussion}

In order to evaluate the advantages of proposed NBT model, two observation cases based on 14 different evidences were given (case A and case B listed in Table 8 and Table 9, respectively). According to these observation cases, the proposed model found out the possibility of obtaining the optimum opportunity of NBT. To clarify the listed evidence in Table 8 and Table 9 more, it is worth mentioning that the BE5 in Table 8 addressed the scenario in which the BS is given to be well-equipped and GC is compliant. Accordingly, by WE3 scenario (Table 9), poorly planned SEF is set as the new evidence.

The line graphs in Figures 8 and 9 represent the probability of four NBT indexes, that is, very high index (VHI), high index (HI), moderate index (MI) and low index (LI), in the light of new evidences presented in Table 8 and Table 9. Both graphs started with prior probability (PP) of four-index and carried on with posterior probability given different observations.

In the NBT condition, given case A, except for VHI, the rest of indexes experienced a steady deterioration. Given single evident observations (BE1; compliance of GC, BE2; wellplanned SEF and BE4; well-equipped BS), making BS well-equipped (BE4) would lead to more satisfaction for NBT as the VHI has sharper increase considering this observation. Besides, a comparison on VHI posterior probability given BE3 (compliance of GC and well-planned SEF) and BE4 (well-equipped BS) reveals that focusing only on BS is more profitable and efficient than even working on SEF and GC. This reasoning can be accounted as a short-term decisionmaking solution for making the NBT more powerful.

Table 3.

Summary of wellknown status

\begin{tabular}{lcc}
\hline & Number of BS & Probability \\
\hline Advertised & 14 & 0.35 \\
Partially known & 21 & 0.5 \\
Unknown & 6 & 0.15 \\
\hline
\end{tabular}

\begin{tabular}{lcc}
\hline & Number of BS & Probability \\
\hline Full & 7 & 0.2 \\
Partially & 26 & 0.7 \\
No & 3 & 0.1 \\
\hline
\end{tabular}

\section{Table 4.}

Summary of protected area overall condition

\begin{tabular}{lcc}
\hline & Number of BS & Probability \\
\hline H1; human guide of [0-250] & 11 & 0.3 \\
H2; human guide of [250-500] & 16 & 0.45 \\
H3; human guide more than 500 & 9 & 0.25 \\
\hline
\end{tabular}



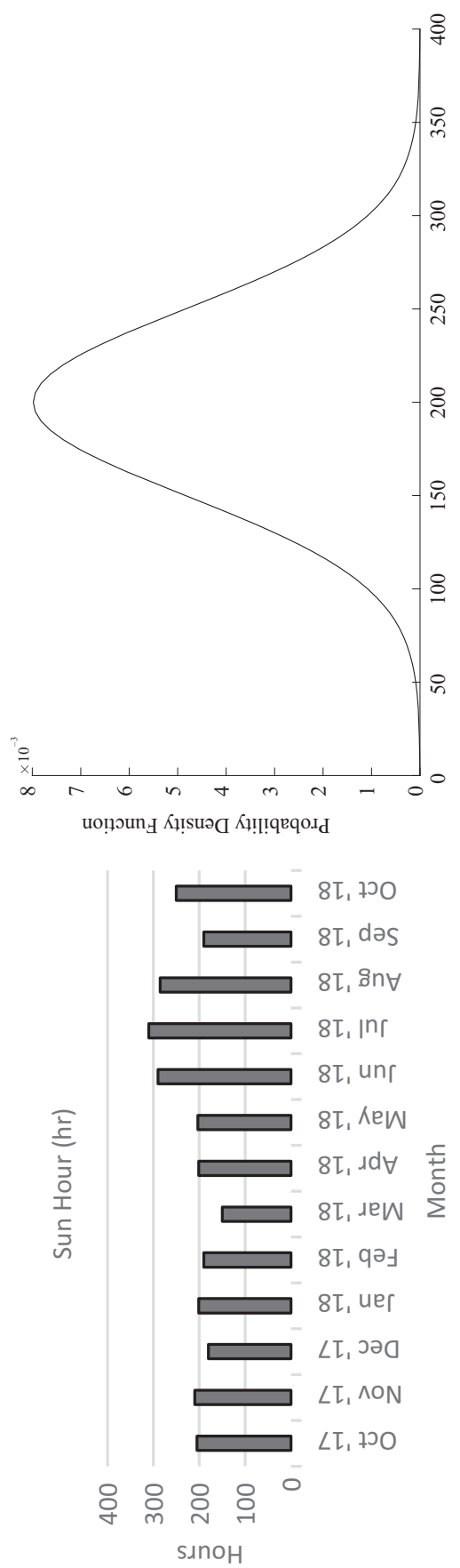
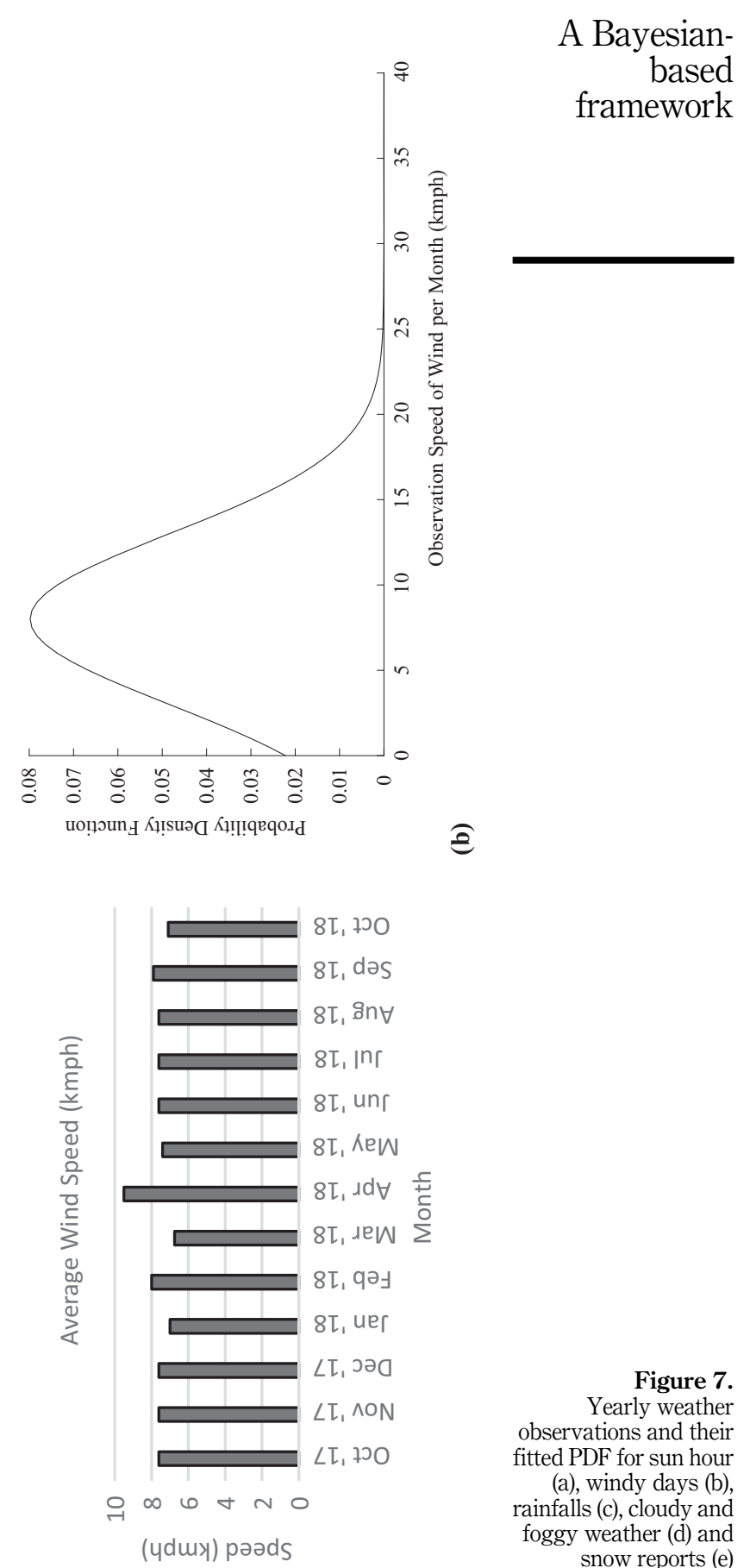

Figure 7.

Yearly weather observations and their fitted PDF for sun hour (a), windy days (b), rainfalls (c), cloudy and foggy weather (d) and snow reports (e) 


\section{JABES}
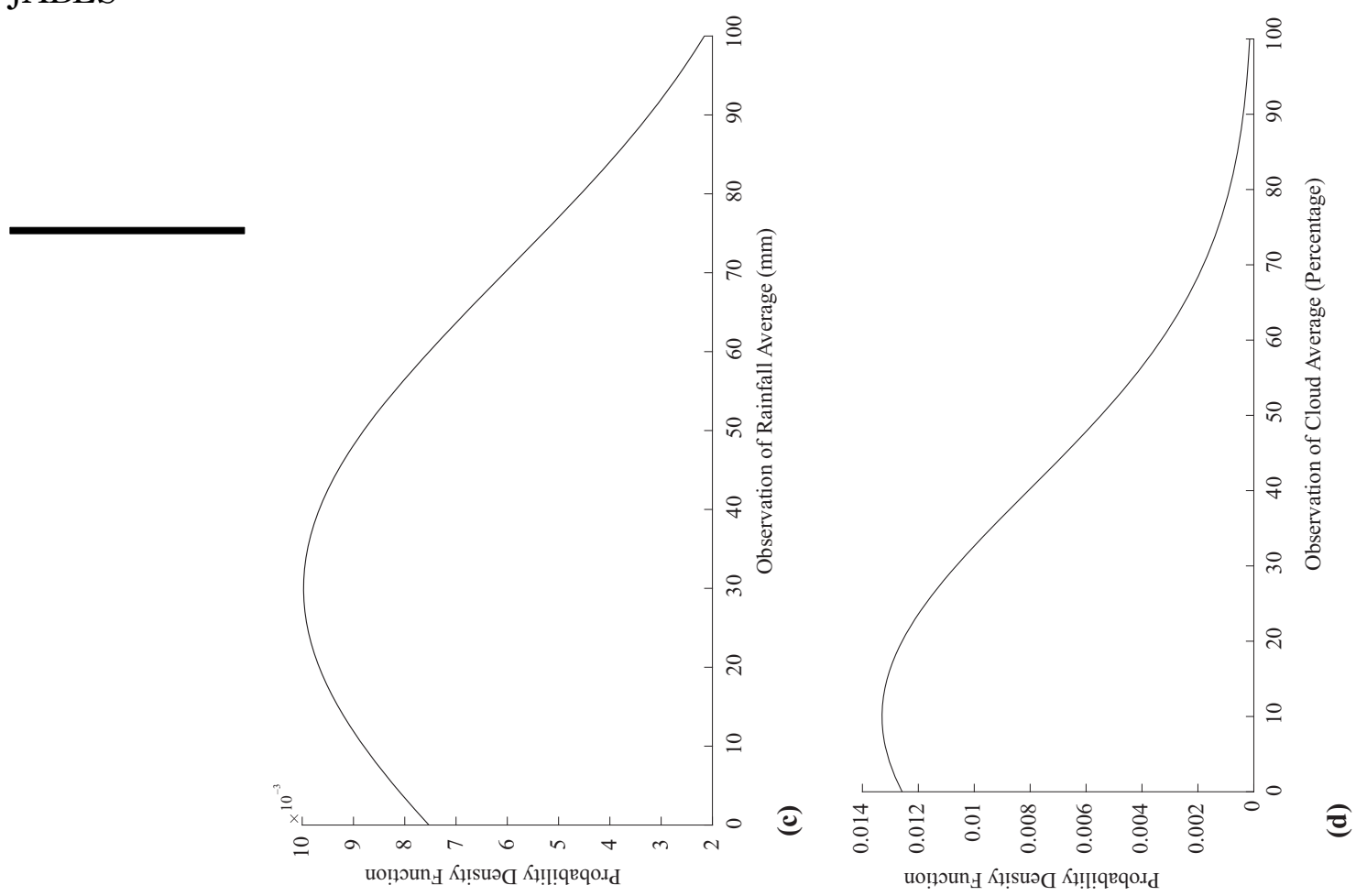

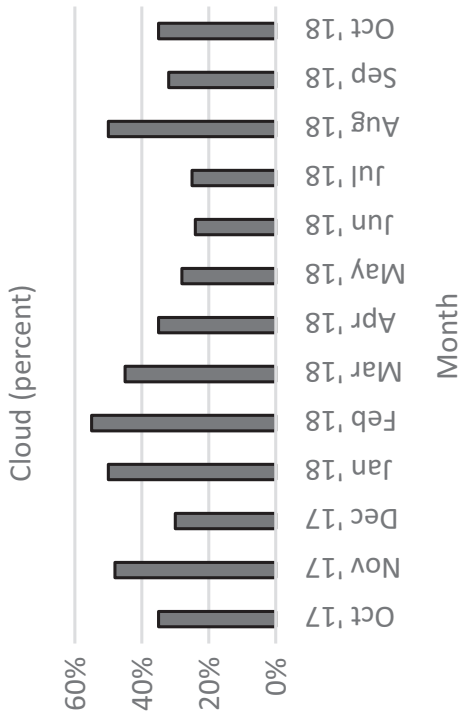

(\%) pnop

Figure 7.

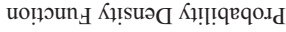

(mu) ॥едu!̣ey

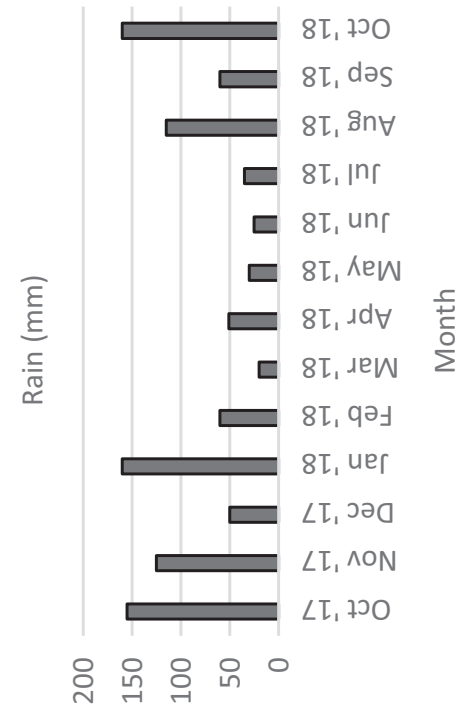

(\%) pnoj 


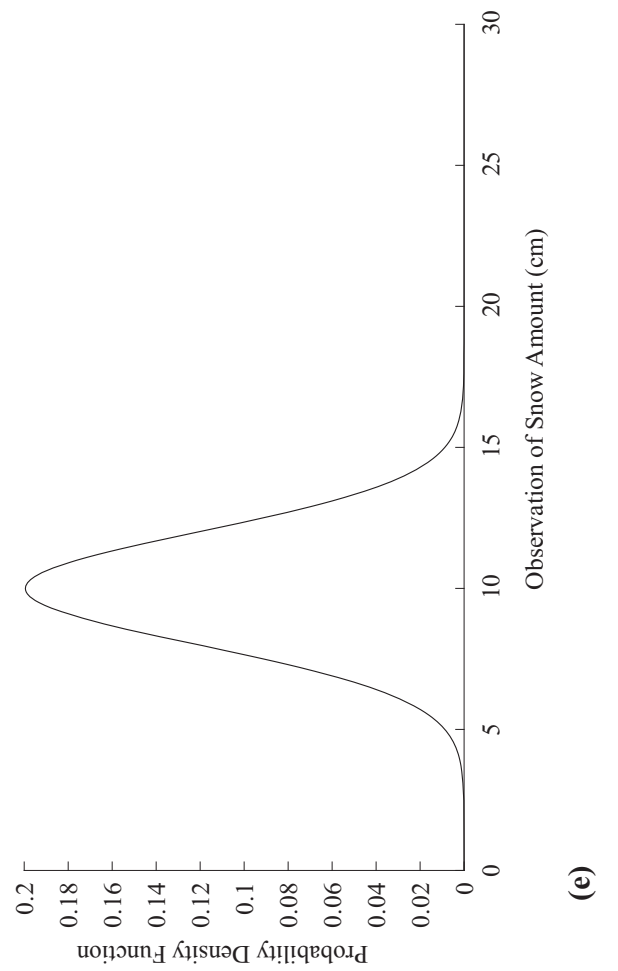

A Bayesianbased framework

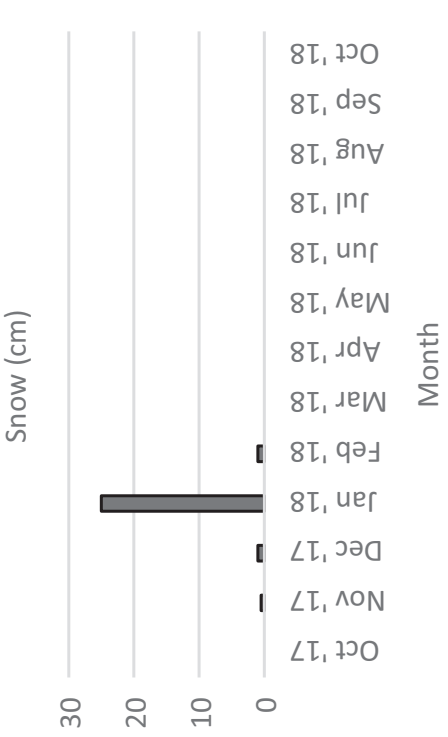

(uכ) ॥еумоus

Figure 7. 
On the contrary, tracking the impact of case B evidences on the prior probability of NBT indexes proves that inadequate performance of SEF variable has bolder negative impact on NBT in comparison to BS and GC. It is proved by, first, drawing a comparison between LI index of WE2 (nonequipped BS) and WE3 (poorly planned SEF). It can be seen in Figure 8 (b) that although the VHI state of WE2 (nonequipped BS) and WE3 (poorly planned SEF) are both zero, the LI of WE3 is noticeably higher than WE2. And second, the trend of LI maintained the same level and even experienced a slight decrease through the WE3 (poorly planned SEF) and WE4 (noncompliance of GC and nonequipped BS) observations. Subsequently, the SEF status should be considered to have more satisfaction in the NBT system.

\begin{tabular}{llc}
\cline { 2 - 3 } & Weather condition & Probability \\
\cline { 2 - 3 } Table 6. & Sunny & 0.35 \\
The portion of each & Rainy & Snowy \\
weather conditions in & Cloudy and foggy & 0.35 \\
a year & Windy & 0.05 \\
\hline
\end{tabular}

Nature

Percentage of coverage

$\begin{array}{lr}\text { Beach } & 0.24 \\ \text { Mountain } & 0.19\end{array}$

$\begin{array}{lll}\text { Table 7. } & \text { Mountain } & 0.19 \\ \text { Nature scenery } & \text { Jungle } & 0.47\end{array}$

environment coverage Plain 0.1

Table 8. $\quad$ BE4 $\quad$ Well-equipped beautiful scenery

Possible opportunity to BE6 Well-equipped beautiful scenery and well-planned socioeconomic factor

activate more potential BE7 Well-equipped beautiful scenery and well-planned socioeconomic factor and compliance of good in NBT climate

\begin{tabular}{ll}
\hline Scenario & Evidence \\
\hline PP & Prior probability \\
WE1 & Noncompliance of good climate \\
WE2 & Nonequipped beautiful scenery \\
WE3 & Poorly planned socioeconomic factor \\
WE4 & Noncompliance of good climate and nonequipped beautiful scenery \\
WE5 & Noncompliance of good climate and poorly planned socioeconomic factor \\
WE6 & Poorly planned socioeconomic factor and nonequipped beautiful scenery \\
WE7 & Noncompliance of good climate and poorly planned socioeconomic factor and nonequipped \\
& beautiful scenery
\end{tabular}

Table 9.
List of worse evidences

\begin{tabular}{ll}
\hline Scenario & Evidence \\
\hline PP & Prior probability \\
BE1 & Compliance of good climate \\
BE2 & Well-planned socioeconomic factor \\
BE3 & Compliance of good climate and well-planned socioeconomic factor \\
BE4 & Well-equipped beautiful scenery \\
BE5 & Well-equipped beautiful scenery and compliance of good climate \\
BE6 & Well-equipped beautiful scenery and well-planned socioeconomic factor \\
BE7 & Well-equipped beautiful scenery and well-planned socioeconomic factor and compliance of good \\
& climate
\end{tabular}




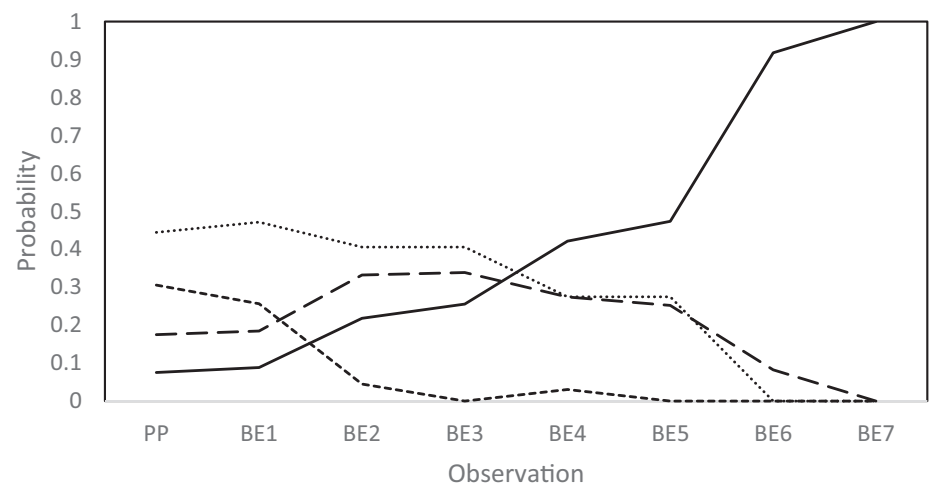

— Very High Index — - - High Index

Moderate Index

Low Index

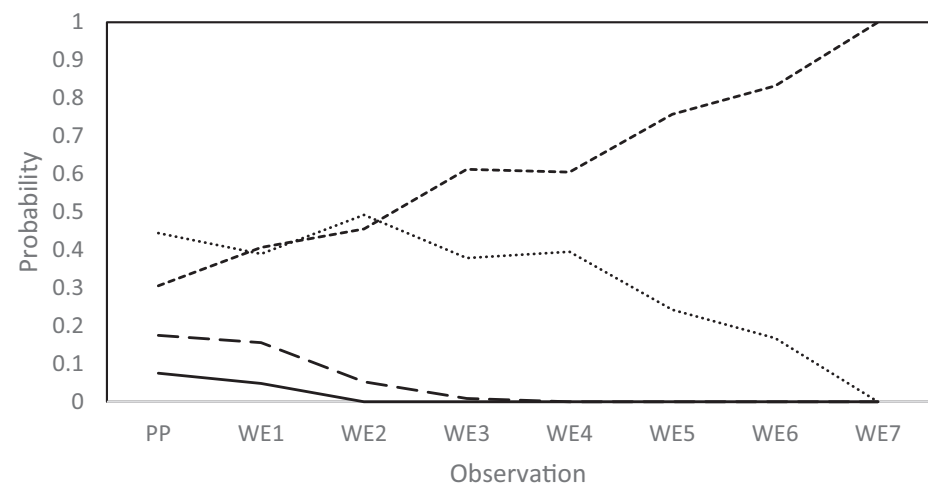

Very High Index — - - High Index
A Bayesianbased framework

Figure 8.

NBT posterior probability in the light of new evidences for case A

Figure 9. NBT posterior probability in the light of new evidences for case B

In the light of BE7 evidence, the posterior probability of VHI of NBT raised to be a sure event (event with probability equal to 1). The reported description of BE7 (see Table 7) depicts that GC, BS and SEF are set to be $100 \%$ at their optimum status, which are compliance, wellequipped and well-planned, respectively.

Revising BN parameters using backpropagation approach leads to calculate the least necessary contribution of key factors to achieve the certain VHI of NBT. As it is shown in Figure 10, this logic is similarly applied to estimate the probability of all key factors given that the NBT was set in its different configurations. These posterior probabilities resulting from proposed $\mathrm{BN}$ show that obtaining a very high quality NBT does not necessarily requires all the key factors to be perfect. Accordingly, based on Bayesian propagation, if the probability of optimum status of GC, BS and SEF simultaneously stood more than $0.79,0.29$ and 0.91 , respectively, a highly qualified NBT will be gained. On the contrary, the policymakers, organizations, government and so on have to be aware that low index of NBT is not equal to having nothing. As an instance and as it can be seen easily in Figure 10, if the probability of the key factors stays on white zone, although there are not zero, the resulted NBT would be a low-index one. 


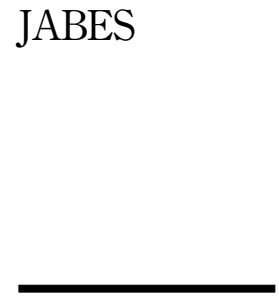

Figure 10.

The least contribution of first, second and third-level factors to obtain certain VHI of NBT

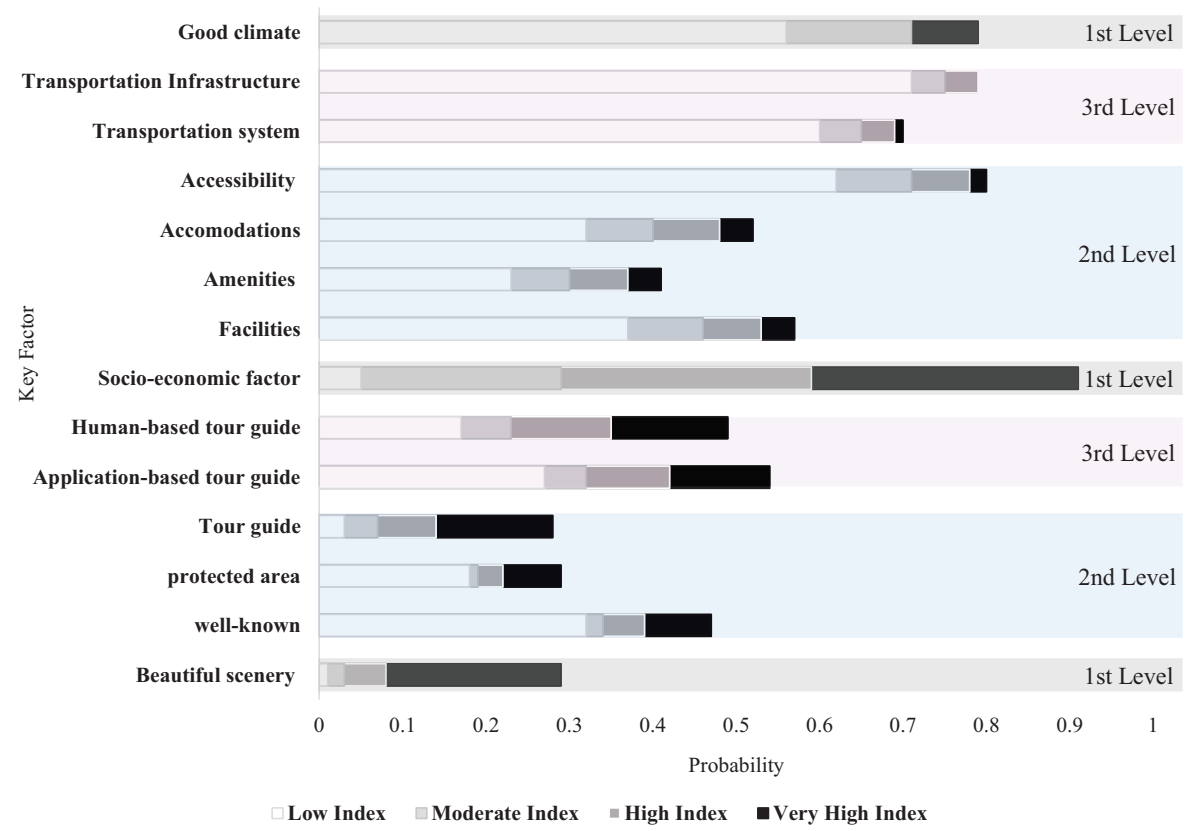

\section{Conclusion}

This paper attempts to provide a framework by which decision-making process for NBT stakeholders and related decision and policymakers would become more efficient. For this purpose, $\mathrm{BN}$ as probabilistic network has been chosen as it has set of advantages such as performing better in quantifying the uncertainty and solving decision-making problems, over other similar methods such as AHP and MLE. By introducing an NBT model and mapping it on BN, different scenarios of NBT optimization through introducing new evidences in the BN can be presented. This will help policymakers in different levels of authority to make better, more efficient and more logical decisions to improve the state of NBT in a particular destination.

In this study, a novel NBT model was implemented through the BN of 17 variables. There are a variety of key factors influencing the NBT. These key factors were categorized in three main groups: beautiful scenery representing the nature condition, socioeconomic factor, depicts the economic and management impact, good climate; reflex the weather condition in the study. These three groups were arranged throughout three levels according to the intensity of their effects on NBT status. The root nodes of BN were quantified based on data provided by local governmental organizations (reference), documents and expert judgment. To demonstrate the applicability of the methodology, two cases of observations are considered. The proposed model highlighted that focusing on BS alone is more profitable and efficient than even working on SEF and GC. On the contrary, it is proved that poor performance of SEF variable has bolder negative impact on NBT in comparison to BS and GC. Furthermore, backpropagation approach of BN led to calculation of the least necessary contribution of key factors to achieve the certain index of NBT. 


\section{References}

Akama, J.S. (1996), "Western environmental values and nature-based tourism in Kenya", Tourism Management, Vol. 17 No. 8, pp. 567-574.

Ashworth, G. and Page, S.J. (2011), "Urban tourism research: recent progress and current paradoxes", Tourism Management, Vol. 32 No. 1, pp. 1-15.

Assaf, A.G. and Tsionas, E.G. (2015), "Incorporating destination quality into the measurement of tourism performance: a Bayesian approach”, Tourism Management, Vol. 49, pp. 58-71.

Assaf, A.G., Oh, H. and Tsionas, M. (2017), "Bayesian approach for the measurement of tourism performance: a case of stochastic Frontier models”, Journal of Travel Research, Vol. 56 No. 2 , pp. 172-186.

Assaf, A.G., Tsionas, M. and Tasiopoulos, A. (2019), "Diagnosing and correcting the effects of multicollinearity: Bayesian implications of ridge regression", Tourism Management, Vol. 71, pp. 1-8.

Baggio, R., Scott, N. and Cooper, C. (2010), "Improving tourism destination governance: a complexity science approach”, Tourism Review, Vol. 65 No. 4, pp. 51-60.

BahooToroody, A., Abaei, M.M., Arzaghi, E., BahooToroody, F., De Carlo, F. and Abbassi, R. (2019), "Multi-level optimization of maintenance plan for natural gas system exposed to deterioration process", Journal of Hazardous Materials, Vol. 362, pp. 412-423.

Balmford, A., Beresford, J., Green, J., Naidoo, R., Walpole, M. and Manica, A. (2009), "A global perspective on trends in nature-based tourism”, PLoS Biology, Vol. 7 No. 6, p. e1000144.

Barber, D. (2012), Bayesian Reasoning and Machine Learning, Cambridge University Press, February 2.

Bell, S., Simpson, M., Tyrväinen, L., Sievänen, T. and Pröbstl, U. (Eds) (2009), European Forest Recreation and Tourism: A Handbook, Taylor \& Francis.

Casagrandi, R. and Rinaldi, S. (2002), "A theoretical approach to tourism sustainability", Conservation Ecology, Vol. 6 No. 1, p. 13 (15 pages).

Ceballos-Lascurain, H. (1996), Tourism, Ecotourism, and Protected Areas: The State of Nature-Based Tourism Around the World and Guidelines for its Development, Iucn.

CHHTOI (2018), "Cultural heritage, handicrafts and tourism organization of Iran", available at: http:// www.ichto.ir/.

Coghlan, A. and Buckley, R. (2012), "Nature-based tourism”, The Routledge Handbook of Tourism and the Environment, Routledge, pp. 356-366.

Coughlin, K.M. (2006), Muslim Cultures Today: A Reference Guide, Greenwood Publishing Group.

Council, W.T.a. T. (2007), The Global Travel and Tourism Summit, World Travel and Tourism Council, London.

Cuculeski, N., Petrovska, I. and Petkovska Mircevska, T. (2015), "Emerging trends IN tourism: need for alternative forms IN Macedonian tourism", Review of Innovation and Competitiveness: $A$ Journal of Economic and Social Research, Vol. 1 No. 1, pp. 103-114.

Fossgard, K. and Fredman, P. (2019), "Dimensions in the nature-based tourism experiencescape: an explorative analysis", Journal of Outdoor Recreation and Tourism, Vol. 28, p. 100219.

Fredman, P. and Tyrväinen, L. (2010), "Frontiers in nature-based tourism", Scandinavian Journal of Hospitality and Tourism, Vol. 10 No. 3, pp. 177-189.

Goodwin, H. (1996), "In pursuit of ecotourism", Biodiversity and Conservation, Vol. 5 No. 3, pp. 277-291.

Hsu, C.-I., Shih, M.-L., Huan, B.-W., Li, B.-Y. and Lin, C.-N. (2008), "Combining LISREL and Bayesian network to predict tourism loyalty", Paper Presented at the Neural Networks, 2008. IJCNN 2008. (IEEE World Congress on Computational Intelligence). IEEE International Joint Conference on.
A Bayesianbased framework 
Hsu, F.-M., Lin, Y.-T. and Ho, T.-K. (2012), "Design and implementation of an intelligent recommendation system for tourist attractions: the integration of EBM model, Bayesian network and Google Maps", Expert Systems with Applications, Vol. 39 No. 3, pp. 3257-3264.

Huang, Y. and Bian, L. (2009), "A Bayesian network and analytic hierarchy process based personalized recommendations for tourist attractions over the Internet”, Expert Systems with Applications, Vol. 36 No. 1, pp. 933-943.

IRIMO (2018), "Iran meteorological organization", available at: https://www.irimo.ir/.

IRSO (2018), "Iran statistics organization", available at: https://www.amar.org.ir/.

Kuenzi, C. and McNeely, J. (2008), "Nature-based tourism”, Global Risk Governance, Springer, pp. 155-178.

Leoni, L., BahooToroody, A., De Carlo, F. and Paltrinieri, N. (2018), "Developing a risk-based maintenance model for a natural gas regulating and metering station using bayesian network", Journal of Loss Prevention in the Process Industries, Vol. 57, pp. 17-24.

MacDonald, R. and Jolliffe, L. (2003), "Cultural rural tourism: evidence from Canada", Annals of Tourism Research, Vol. 30 No. 2, pp. 307-322.

Mastny, L. and Peterson, J.A. (2001), Traveling Light: New Paths for International Tourism, Worldwatch Institute, WA, DC.

MEAF (2018), "Iran's ministry of economic affairs and finance", available at: http://www.mefa.gov.ir.

MRUD (2018), "Iran's minstry of road and urban development”, available at: https://www.mrud.ir/.

Myung, I.J. (2003), “Tutorial on maximum likelihood estimation”, Journal of Mathematical Psychology, Vol. 47 No. 1, pp. 90-100, doi: 10.1016/s0022-2496(02)00028-7.

Neapolitan, R.E. (2004), Learning Bayesian Networks, Pearson Prentice Hall, Upper Saddle River, NJ, Vol. 38.

Park, D.-B. and Yoon, Y.-S. (2009), "Segmentation by motivation in rural tourism: a Korean case study", Tourism Management, Vol. 30 No. 1, pp. 99-108.

Pearce, D.G. (2001), "An integrative framework for urban tourism research", Annals of Tourism Research, Vol. 28 No. 4, pp. 926-946.

Pergams, O.R. and Zaradic, P.A. (2008), "Evidence for a fundamental and pervasive shift away from nature-based recreation", Proceedings of the National Academy of Sciences, Vol. 105 No. 7, pp. 2295-2300.

Richards, G. (Ed.) (2007), Cultural Tourism: Global and Local Perspectives, Psychology Press.

Scutari, M. (2014), "Bayesian network constraint-based structure learning algorithms: Parallel and optimised implementations in the bnlearn R package", arXiv preprint arXiv:1406.7648.

Smeral, E. (1988), "Tourism demand, economic theory and econometrics: an integrated approach", Journal of Travel Research, Vol. 26 No. 4, pp. 38-43.

Smith, M.K. (2009), Issues in Cultural Tourism Studies, Routledge, December 4.

Stilo, D.L. (1981), "The Tati language group in the sociolinguistic context of Northwestern Iran and Transcaucasia", Iranian Studies, Vol. 14 Nos 3-4, pp. 137-187.

Ticehurst, J.L., Newham, L.T., Rissik, D., Letcher, R.A. and Jakeman, A.J. (2007), “A Bayesian network approach for assessing the sustainability of coastal lakes in New South Wales, Australia", Environmental Modelling and Software, Vol. 22 No. 8, pp. 1129-1139.

Tyrrell, T.J. and Johnston, R.J. (2008), "Tourism sustainability, resiliency and dynamics: towards a more comprehensive perspective", Tourism and Hospitality Research, Vol. 8 No. 1, pp. 14-24.

Wang, W., Zeng, G., Zhang, D., Huang, Y., Qiu, Y. and Wang, X. (2008), “An intelligent ontology and bayesian network based semantic mashup? For tourism", Paper Presented at the 2008 IEEE Congress on Services 2008-Part I. 
Wilson, S., Fesenmaier, D.R., Fesenmaier, J. and Van Es, J.C. (2001), "Factors for success in rural tourism development", Journal of Travel Research, Vol. 40 No. 2, pp. 132-138.

WWO (2014), "World weather online”, available at: http://www.worldweatheronline.com.
A Bayesianbased framework

\section{Corresponding author}

Mohammad Mahdi Abaei can be contacted at:mahdy.abaiee@gmail.com 